\title{
Viability of human dermal fibroblasts cultured on bacterial cellulose and Aloe vera composites
}

\author{
Lya Piaia*, Camila Quinetti Paes, Luismar Marques Porto \\ From 5th Congress of the Brazilian Biotechnology Society (SBBIOTEC) \\ Florianópolis, Brazil. 10-14 November 2013
}

\begin{abstract}
Background
Development of multifunctional scaffolds has allowed restructuration and improvement of native tissues, presenting characteristics that mimic complex tissues formation [1]. An ideal scaffold should provide enough transport of nutrients and also adequate mechanical support, allowing the incorporation of many cell types. Likewise, biocompatibility, mechanical properties and water retention are other important characteristics of biomaterials used for tissue regeneration [2]. In this perspective, searching for a biomaterial that promote healing and cell development, fractions of Aloe vera combined with bacterial cellulose $(\mathrm{BC})$ are being intensively studied in our laboratory. $B C$ hydrogels present characteristics that provide an optimal environment for cell culture [3,4]. So the combination of biological components of a natural plant and the unique properties of $\mathrm{BC}$ is believed to promote desirable hydrogel-cell interactions and also improvement of the healing dynamics of injured tissues [5]. The objective of this study was to evaluate the viability of human dermal cells when in contact with the novel BC-Aloe vera composites.
\end{abstract}

\section{Methods}

BC-Aloe vera composites were developed using G. hansenii bacterial strain ATCC23769. The culture medium used for the production of $\mathrm{BC}$ membranes consisted of mannitol, yeast extract and peptone. For the composites, fractions of Aloe vera (gel, total gel and polysaccharide fraction 1) were added to the membranes in a concentration of $40 \%$, at temperature of $25^{\circ} \mathrm{C}$, under static conditions for 10 days. After that, membranes were washed with solution of $\mathrm{NaOH}\left(0,1 \mathrm{~mol} \mathrm{~L}^{-1}\right)$, sterilized by autoclaving and stored in cool and dry place until use. In order to evaluate the cell viability, primary cultures of Human
Dermal Fibroblasts adult cells (HDFa) were grown in Dulbecco's Modified Eagle Medium (DMEM) in a humidified atmosphere, at $37^{\circ} \mathrm{C}$ with $5 \%$ of $\mathrm{CO}_{2}$. Groups of investigation consisted of pure $\mathrm{BC}$ and $\mathrm{BC}$ composed with fractions of Aloe vera extract Cell viability was determined using the colorimetric assay MTS [3-(4,5- dimethylthiazol2-yl)-5-(3-carboxymethoxyphenyl) 2-(4-sulfophenyl)-2Htetrazolium]. Cells were seeded in a concentration of $10^{5}$ cell/membrane, grown in the porous side of the membrane and analyzed at 24, 48, $72 \mathrm{~h}$ and 7 days of culture. Absorbance at $490 \mathrm{~nm}$ was quantified in a microplate reader. In parallel to the MTS assay we also performed qualitative analysis of cell viability by Live/Dead ${ }^{\mathbb{R}}$ test.

\section{Results and conclusions}

Results indicated a good interaction between the cells and the $\mathrm{BC}$ composites, which was indicated by the stable cell viability observed over time. In 24 hours, we could observe an increase of cell viability in all groups when compared the control. After this time point, there was a slight decrease in cell viability, possibly caused by natural cell senescence, but remained cells were still viable. Those findings could be confirmed by the qualitative analysis $\left(\right.$ Live/Dead ${ }^{\circledR}$ ), which showed good cell adhesion and viability over all time points. Interestingly, cell spreading was even observed at day 7. Considering these initial results, we could concluded that the formulated composites have a great potential to be used in several biomedical applications, especially for epithelial tissue repair.

\section{Acknowledgements}

CAPES, CNPq, FINEP.

Published: 1 October 2014 


\section{References}

1. Pampaloni F, Reynaud EG, Stelzer EHK: The third dimension bridges the gap between cell culture and live tissue. Nature Reviews Molecular Cell Biology 2007, 8(10):839-845.

2. Recouvreux DOS, Rambo CR, Bertil FV, Carminatti CA, Antônio RV, Porto LM: Novel three-dimensional cocoon-like hydrogels for soft tissue regeneration. Materials Science and Engineering: C 2011, 31(2):151-157.

3. Andersson J, Stenhamre H, Bäckdahl H, Gatenholm P: Behavior of human chondrocytes in engineered porous bacterial cellulose scaffolds. Journal of Biomedical Materials Research Part A 2010, 94A(4):1124-1132.

4. Klemm D, Kramer F, Moritz S, Lindstrom T, Ankerfors M, Gray D, Dorris A: Nanocelluloses: a new family of nature-based materials. Angewandte Chemie International 2011, 50(24):5438-5466.

5. Mcanalley BH, Mcdaniel HR, Carpenter RH: Wound healing accelerated by systemic administration of polysaccharide from Aloe vera. United States Patent 1994, Patent number 5,468,737.

doi:10.1186/1753-6561-8-S4-P61

Cite this article as: Piaia et al:: Viability of human dermal fibroblasts cultured on bacterial cellulose and Aloe vera composites. BMC Proceedings 2014 8(Suppl 4):P61.

\section{Submit your next manuscript to BioMed Central} and take full advantage of:

- Convenient online submission

- Thorough peer review

- No space constraints or color figure charges

- Immediate publication on acceptance

- Inclusion in PubMed, CAS, Scopus and Google Scholar

- Research which is freely available for redistribution

Submit your manuscript at www.biomedcentral.com/submit
C Biomed Central 